\author{
How to cite this article: \\ Authors: Aneta Łętocha, Daniel Toboła, Tatiana Miller \\ Title of article: „Surface topography analysis of Vanadis 6 tool steel after selected sequential surface treatment pro- \\ cesses" \\ Mechanik, No. 12 (2018) \\ DOI: https://doi.org/10.17814/mechanik.2018.12.200
}

\title{
Surface topography analysis of Vanadis 6 tool steel after selected sequential surface treatment processes
}

\author{
ANETA ŁĘTOCHA \\ DANIEL TOBOŁA \\ TATIANA MILLER *
}

\begin{abstract}
Mgr inż. Aneta Łętocha , aneta.letocha@ios.krakow.pl, https://orcid.org/0000-0001-8363-1294 - Sieć Badawcza Łukasiewicz - Instytut Zaawansowanych Technologii Wytwarzania; Kraków, Polska

Dr inż. Daniel Toboła, daniel.tobola@ios.krakow.pl, https://orcid.org/0000-0001-7966-240X - Sieć Badawcza Łukasiewicz - Instytut Zaawansowanych Technologii Wytwarzania; Kraków, Polska

Mgr inż. Tatiana Miller, tatiana.miller@ios.krakow.pl https://orcid.org/0000-0001-7348-231X - Sieć Badawcza Łukasiewicz - Instytut Zaawansowanych Technologii Wytwarzania; Kraków, Polska
\end{abstract}

Issues related with an influence of selected sequential surface treatment processes on the stereometric features of the formed surface layer (SL) of Vanadis 6 steel are presented. Some variants of machining include: turning (T), turning-burnishing (TB), turning-burnishing-nitriding (TBN), turning-burnishing-sulfonitriding (TBSN) and turning-burnishing-PVD coating (TBPVD). Studies were carried out by contact profiling method with use TOPO 01P device - produced by The Institute of Advanced Manufacturing Technology. Qualitative changes in the graphs of examined surfaces and also changes in the results of surface roughness parameters and profile were analyzed.

KEYWORDS: surface geometrical structure, contact methods of roughness measurement, mechanical machining, sequential treatment, tool steel

Due to diversity of working conditions of cold forming tools and requirements imposed on them, numerous grades of tool steels have been developed. A very important feature of the tools used for this type of processing is the surface roughness of their working parts - it can have a large impact on the quality of manufactured items.

One of the materials with favourable microstructure is Vanadis 6 tool steel, obtained by powder metallurgy.: This steel is characterized by high resistance to abrasive wear, and at the same time, good toughness due to the form and arrangement of alloy carbides.

Processes such as turning or burnishing change the physical properties of SL, while vacuum nitriding and sulfonitriding cause SL chemical changes relative to the core material. The method of physical vapour deposition (PVD) allows, in turn, a permanent coating deposition onto the surface of a detail. The use of these processes leads to a strengthening of the surface - due to which, machine elements and tools can be used longer, which converts into reduced production costs.

These types of mechanical finishing enable shaping the geometric structure of the surface (SGS). However, the machining does not always meet the surface quality requirements. The method that allows to overcome these technological barriers is burnishing, which is used mainly for smooth processing of hard materials and ensures obtaining a surface with low roughness $(R a \approx 0.1 \mu \mathrm{m})$.

Surfaces of the elements after nitriding are characterized by high hardness and abrasion resistance [1-4]. A similar process is sulfonitriding that gives the surface high wear resistance, lowers the friction coefficient and increases the fatigue strength, hardness and corrosion resistance. Sulfonitriding is carried out in an atmosphere of ammonia and sulfur vapours, therefore the result of this process is a nitrided layer (as in classical nitriding) enriched with iron sulfides [5].

Elements protected with PVD coatings are characterized by high hardness, as well as resistance to high temperature and chemical impact as well as to wear [6-7].

As part of the research, the issue of the impact of selected sequential surface machining processes on the stereometric features of shaped SL was undertaken. 


\section{Experimental details}

The test samples were made of Vanadis 6 tool steel, with chemical composition given in Table I. Their heat treatment was carried out in a vacuum furnace even-with gas quenching - a hardness of $62 \pm 1 \mathrm{HRC}$ was obtained.

\section{TABLE I. Chemical composition of Vanadis steel 6}

\begin{tabular}{|c|c|c|c|c|c|c|}
\hline Element & $\mathrm{C}$ & $\mathrm{Si}$ & $\mathrm{Mn}$ & $\mathrm{Cr}$ & Mo & $\mathrm{V}$ \\
\hline Weight, \% & 2.1 & 1.0 & 0.4 & 6.8 & 1.5 & 5.4 \\
\hline
\end{tabular}
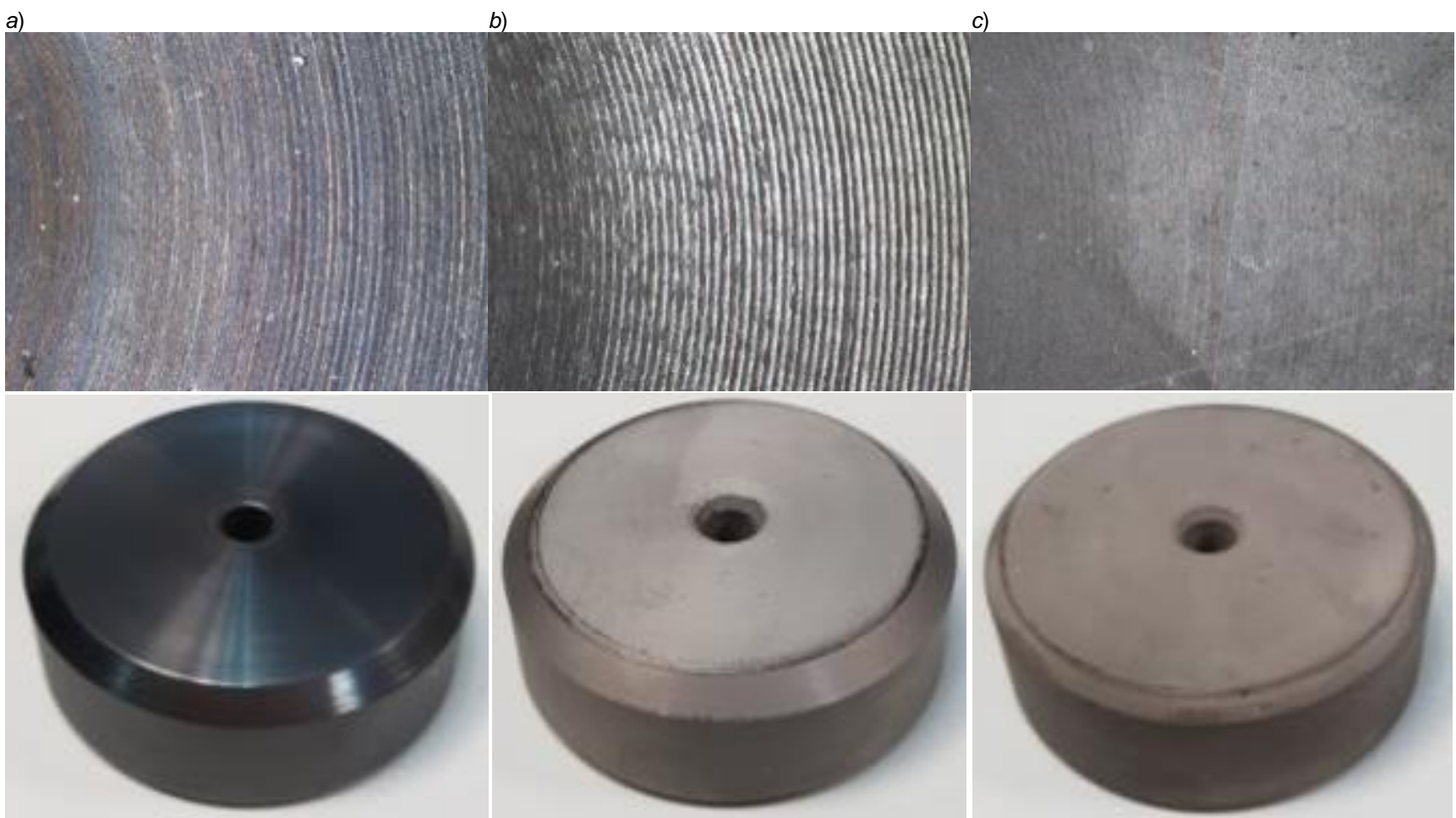

Fig. 1. Images of selected samples with their surfaces after machining: a) TBPVD, b) TBN, c) TBSN (surface images were recorded with a CCD camera attached to the Altimet 520 measuring system)
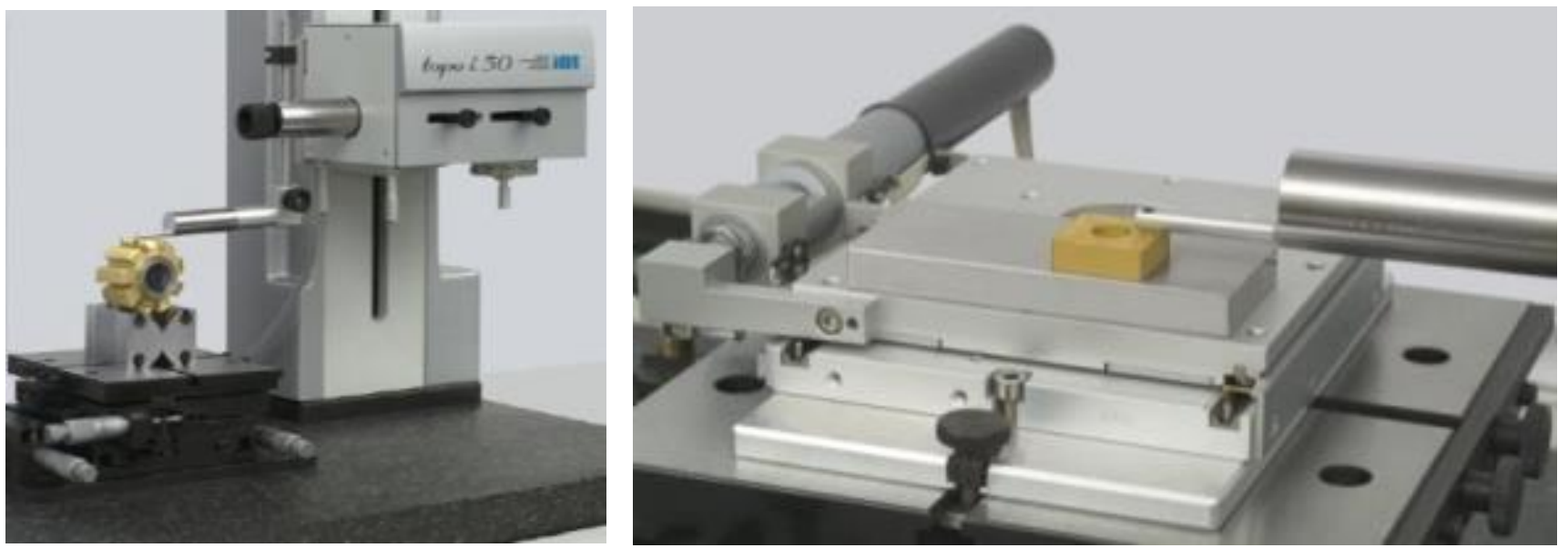

Fig. 2. TOP0 01P measuring system

Selected machining variants were used (fig. 1) with the following parameters: 
-turning (T): cutting speed $v c=100 \mathrm{~m} / \mathrm{min}$, feedrate $f=0.07 \mathrm{~mm} / \mathrm{rev}$;

-turning-burnishing (TB):

- turning parameters as above,

- burnishing: force $F=180 \mathrm{~N}$, feedrate $f=0.02 \mathrm{~mm} / \mathrm{rev}$;

- turning-burnishing-nitriding (TBN):

- turning and burnishing as above,

- nitriding: stage I - $540{ }^{\circ} \mathrm{C} / 8 \mathrm{~h}$, stage II $-540{ }^{\circ} \mathrm{C} / 4 \mathrm{~h}$;

- turning-burnishing-sulfonitriding (TBSN):

- turning and burnishing as above,

- sulfonitriding: stage I $-450^{\circ} \mathrm{C} / 1 \mathrm{~h}$, stage II $-540^{\circ} \mathrm{C} / 10 \mathrm{~h}$;

- turning-burnishing-PVD AlCrN coating (TBPVD):

- turning and burnishing as above,

- coating: process temperature $500{ }^{\circ} \mathrm{C}$.

Tests were carried out using the TOPO 01P contact device for measuring the geometrical structure of the surface (SGS), manufactured by the Institute of Advanced Manufacturing Technologies (fig. 2), equipped with a measuring head with a $2 \mu \mathrm{m}$ diamond tip radius and a $60^{\circ}$ cone angle.

The areas were $4 \times 3.4 \mathrm{~mm}$, with a scanning density: $0.5 \mu \mathrm{m}$ in the measurement axis and $10 \mu \mathrm{m}$ in the direction perpendicular to the measurement axis. When processing the measured data, Gauss filtration was used in accordance with ISO 16610-21. Qualitative changes of studied surfaces, related to stereometric graphs, contour maps and material ratio curves with the marked roughness core, were analyzed. Statistical analysis of height parameters of roughness ( $S q, S p, S v, S z, S a, R p, R v, R z, R a, R q$ ) and core roughness parameters ( $S k, S p k, S v k, R k$, $R p k, R v k$ ) were performed.

\section{Results}

The research results were divided into two groups. The first (designated G1) covered the analysis of SGS changes after T, TB and TBPVD processes, and the second (marked G2) - after TB, TNA and TBSN-processes.

Figs. 3 and 4 contain surface topography graphs and contour maps of samples for groups G1 and G2. Fig. 5 shows changes in material ratio curves depending on the surface machining method used, and fig. 6 shows changes in the roughness profile.
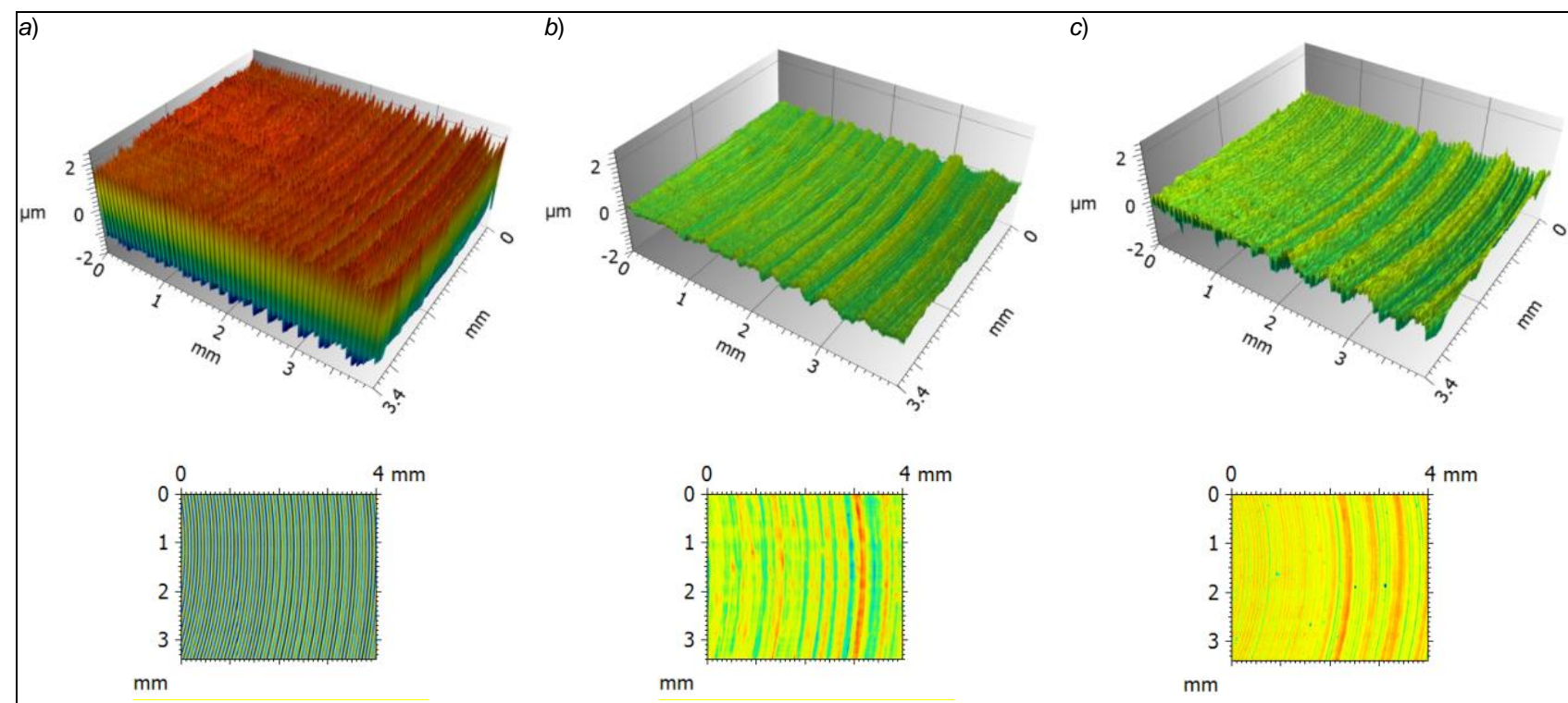

Fig. 3. Surface topography graphs and contour maps for samples from the G1 group, respectively after processes: a) T, b) TB, c) TBPVD 

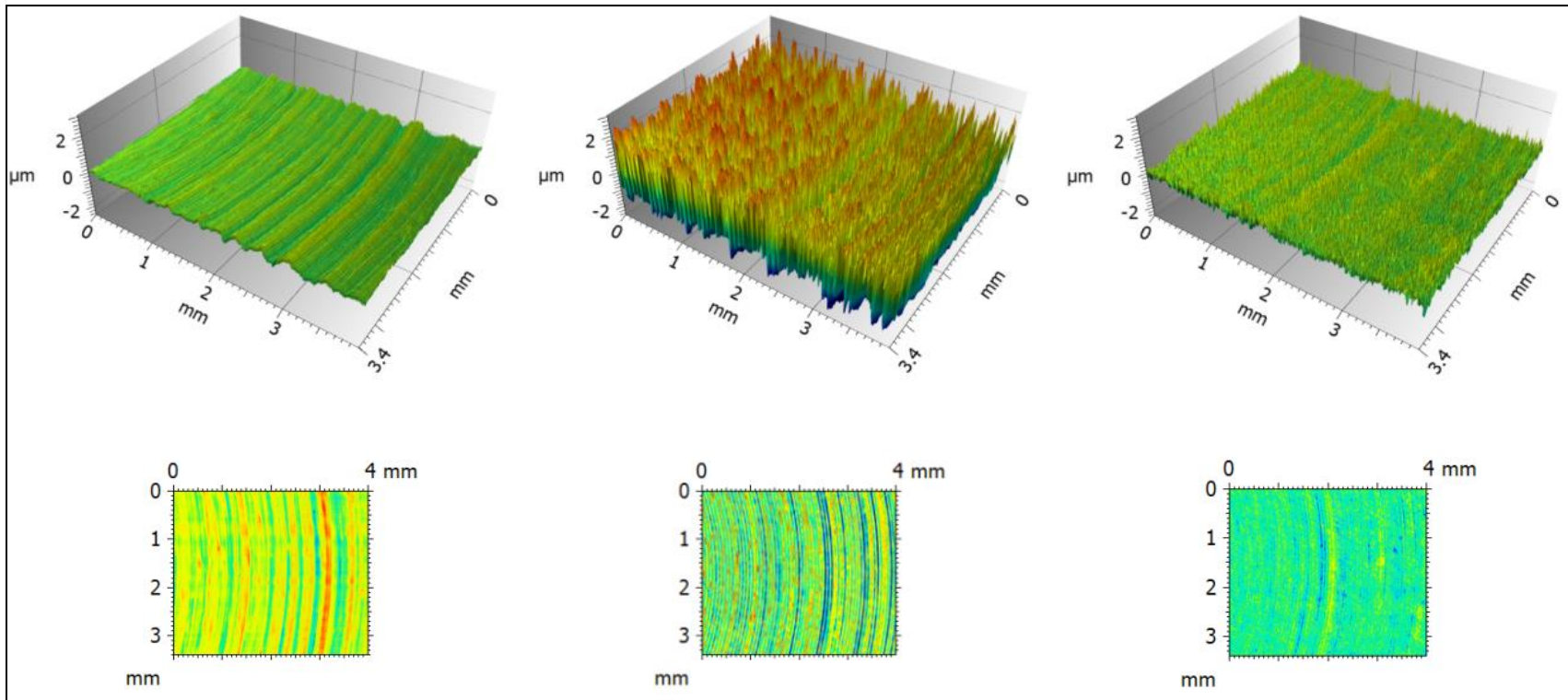

Fig. 4. Surface topography graphs and contour maps for samples from the G2 group, respectively after following processes: a) TB, b) TBN, c) TBSN
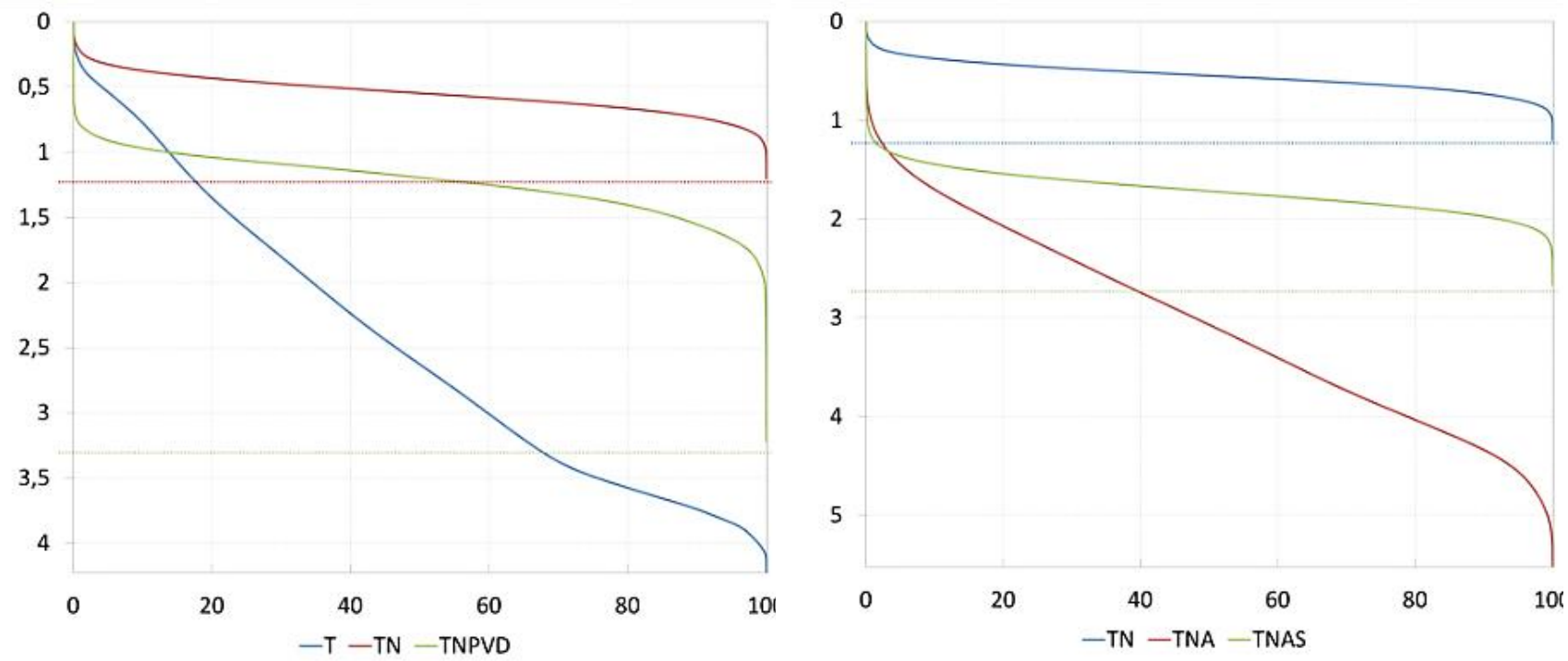

Fig. 5. Comparison of material ratio curves depending on the surface machining method used: a) G1 group, b) $G 2$ group 


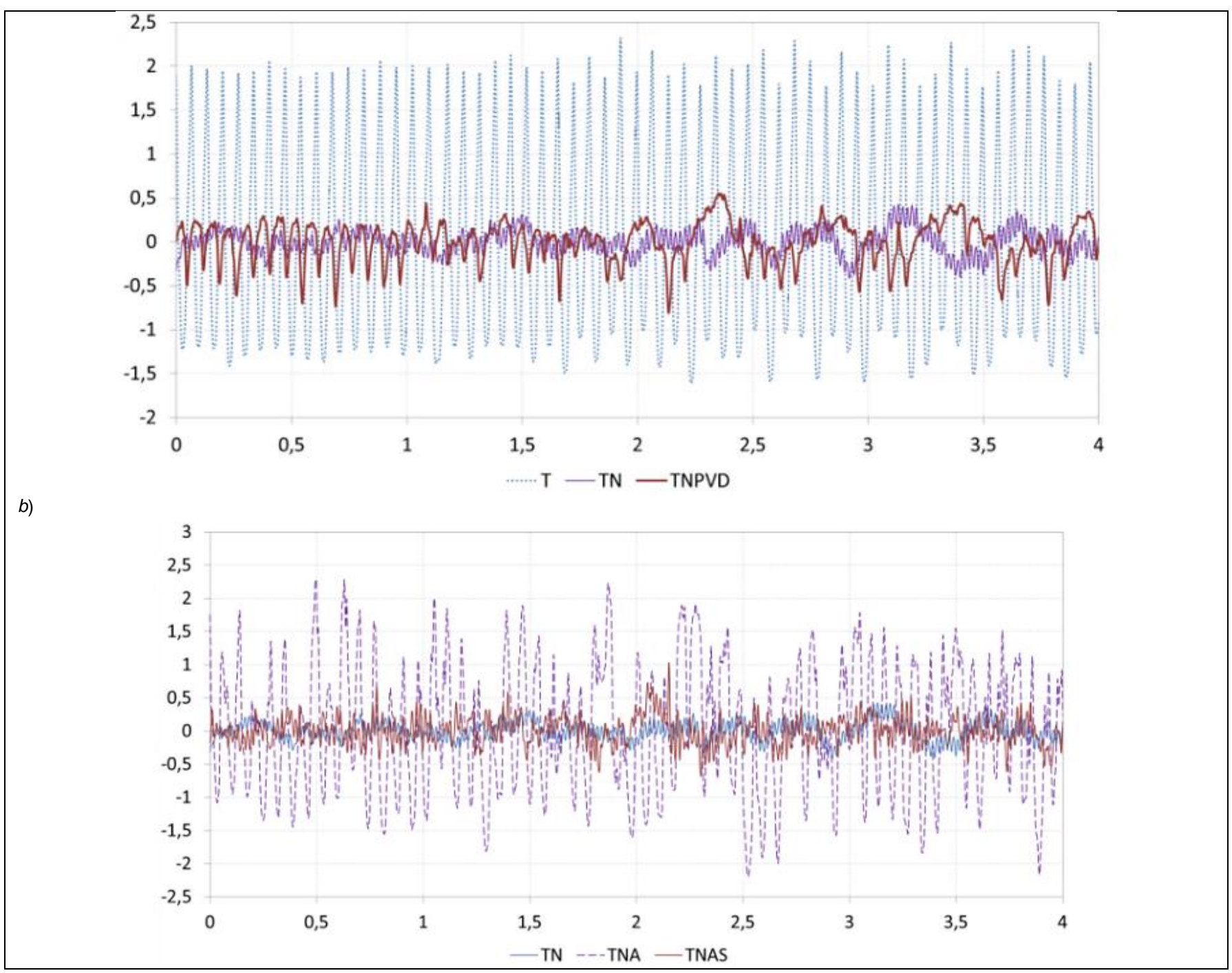

Fig. 6. Changes in the roughness profile for samples from the group: a) $G 1$, b) $G 2$

The resulting surface roughness parameters for the tested machining variants are summarized in table II, while in tables III and IV, mean values and standard deviations for recorded parameters of roughness profile are given. The results apply to samples from groups $G 1$ and $G 2$.

The level of isotropy of the surface of the tested samples after subsequent machining stages indicates slight changes in periodicity:

- $\mathrm{T}-9.18 \%$

-TB $-3.49 \%$

-TBPVD - 4.46\%

-TBN - $11.54 \%$

- TBSN - 5.73\%

TABLE II. Surface roughness parameters of samples from groups G1 and G2

\begin{tabular}{|c|c|c|c|c|c|}
\hline Machining & T & TB & TBPVD & TBN & TBSN \\
\hline$S q, \mu \mathrm{m}$ & 1.090 & 0.140 & 0.276 & 0.903 & 0.198 \\
\hline$S p, \mu \mathrm{m}$ & 2.470 & 0.551 & 1.064 & 2.589 & 1.548 \\
\hline$S v, \mu \mathrm{m}$ & 1.750 & 0.653 & 2.326 & 2.251 & 1.750 \\
\hline$S z, \mu \mathrm{m}$ & 4.220 & 1.204 & 3.390 & 4.840 & 3.298 \\
\hline$S a, \mu \mathrm{m}$ & 0.945 & 0.111 & 0.212 & 0.771 & 0.154 \\
\hline$S k, \mu \mathrm{m}$ & 2.523 & 0.355 & 0.552 & 2.559 & 0.491 \\
\hline$S p k, \mu \mathrm{m}$ & 1.185 & 0.125 & 0.143 & 0.392 & 0.219 \\
\hline$S v k, \mu \mathrm{m}$ & 0.121 & 0.151 & 0.478 & 0.581 & 0.201 \\
\hline
\end{tabular}


TABLE III. Profile roughness parameters for $G 1$ samples

\begin{tabular}{|c|c|c|c|c|c|c|}
\hline \multirow{3}{*}{$\begin{array}{c}\text { Machining } \\
R p, \mu \mathrm{m}\end{array}$} & $\mathrm{T}$ & TB & TBPVD & $\mathrm{T}$ & TB & TBPVD \\
\hline & \multicolumn{3}{|c|}{ average value } & \multicolumn{3}{|c|}{ standard deviation } \\
\hline & 2.253 & 0.314 & 0.448 & 0.036 & 0.014 & 0.052 \\
\hline$R v, \mu \mathrm{m}$ & 1.528 & 0.340 & 0.926 & 0.015 & 0.020 & 0.094 \\
\hline$R z, \mu \mathrm{m}$ & 3.781 & 0.655 & 1.373 & 0.037 & 0.031 & 0.116 \\
\hline$R a, \mu \mathrm{m}$ & 0.947 & 0.110 & 0.210 & 0.004 & 0.005 & 0.012 \\
\hline$R q, \mu \mathrm{m}$ & 1.093 & 0.135 & 0.270 & 0.006 & 0.006 & 0.017 \\
\hline$R k, \mu \mathrm{m}$ & 2.510 & 0.351 & 0.543 & 0.034 & 0.015 & 0.031 \\
\hline$R p k, \mu \mathrm{m}$ & 1.213 & 0.122 & 0.146 & 0.036 & 0.010 & 0.028 \\
\hline$R v k, \mu \mathrm{m}$ & 0.104 & 0.146 & 0.470 & 0.019 & 0.010 & 0.039 \\
\hline
\end{tabular}

TABLE IV. Profile roughness parameters for G2 samples

\begin{tabular}{|c|c|c|c|c|c|c|}
\hline \multirow{2}{*}{ Parameter } & ТВ & TBN & TBSN & $\overline{\mathrm{TB}}$ & TBN & $\overline{\text { TBSN }}$ \\
\hline & \multicolumn{3}{|c|}{ average value } & \multicolumn{3}{|c|}{ standdard deviation } \\
\hline$R p, \mu \mathrm{m}$ & 0.314 & 1.692 & 0.627 & 0.014 & 0.106 & 0.108 \\
\hline$R v, \mu \mathrm{m}$ & 0.340 & 1.778 & 0.486 & 0.020 & 0.086 & 0.095 \\
\hline$R z, \mu \mathrm{m}$ & 0.655 & 3.471 & 1.114 & 0.031 & 0.126 & 0.172 \\
\hline$R a, \mu \mathrm{m}$ & 0.110 & 0.774 & 0.155 & 0.005 & 0.033 & 0.017 \\
\hline$R q, \mu \mathrm{m}$ & 0.135 & 0.902 & 0.196 & 0.006 & 0.035 & 0.026 \\
\hline$R k, \mu \mathrm{m}$ & 0.351 & 2.508 & 0.499 & 0.015 & 0.134 & 0.033 \\
\hline$R p k, \mu \mathrm{m}$ & 0.122 & 0.391 & 0.229 & 0.010 & 0.102 & 0.038 \\
\hline$R v k, \mu \mathrm{m}$ & 0.146 & 0.594 & 0.179 & 0.010 & 0.104 & 0.092 \\
\hline
\end{tabular}

\section{Summary}

After burnishing process, the surface roughness significantly decreases (fig. 3b, tables II-IV), and the maximum surface height decreases by over two-thirds in relation to the turned surface. The material ratio curve becomes symmetrical (fig. 5a). Also, the level of surface isotropy is reduced by more than half.

Similar results were obtained for the surface after the PVD coating was applied and after sulfonitriding. In both cases, the roughness parameters are higher than for the burnished surface, but they do not exceed values obtained for the turned surface (tables II-IV). Samples, on which the PVD coating was applied, are characterized by random, dales, which slightly affects the symmetry of the material ratio curve (fig. 5a). On the other hand, the surfaces after sulfonitriding are characterized by higher number of hills in relation to the dales, which may be caused by sulfides depositing on the surface during the machining process (figs. $5 \mathrm{c}$ and $6 \mathrm{~b}$ ). In both cases, the surface isotropy increases slightly relative to burnishing.

In terms of surface roughness, the worst results were obtained for vacuum nitriding (fig. $4 \mathrm{~b}$ ). A significant increase in roughness parameters, similar to the results obtained for turning alone can be visible (tables II and IV). Despite the increase in surface roughness, the material ratio curve retained its symmetrical character (fig. $5 b)$. The level of surface isotropy also increased, even compared to turned samples. In order to improve the surface roughness parameters of nitrided samples, additional machining, e.g. grinding or polishing, is recommended.

All tested surfaces become less homogeneous after carrying out additional processes, and the standard deviation of the calculated profile roughness parameters increases - the largest increase was recorded for the nitrided surface. Almost all surfaces (except the one after sulfonitriding) maintain similar directionality.

In terms of surface quality and roughness, the best results were obtained for the burnishing process, however the other machining methods give the surface other beneficial properties that cannot be achieved only by burnishing.

The research was carried out as part of the project No. LIDER//13/0075/L-7/15/NCBR/2016 "Development of an innovative technology of obtaining functional properties of cold working tools", financed by the National Centre for Research and Development. 


\section{REFERENCES}

[1] Kula P. „Inżynieria warstwy wierzchniej”. Łódź: Politechnika Łódzka, Łódź, 2000.

[2] Małdziński L. „Termodynamiczne, kinetyczne i technologiczne aspekty wytwarzania warstwy azotowanej na żelazie i stalach w procesach azotowania gazowego". Poznań: Wydawnictwo Politechniki Poznańskiej, 2002.

[3] Zyśk J. „Rozwój azotowania gazowego stopów żelaza”. Warszawa: Instytut Mechaniki Precyzyjnej, 2008.

[4] Toboła D., Rusek P., Polowski W., Czechowski K. „Możliwość poprawy efektów azotowania stali narzędziowej Vanadis 6 poprzez nagniatanie ślizgowe". Mechanik. 8-9 (2012): 700-703.

[5] Binienda M., Just P., Komorowski J., Pokrzywa M., Wołowiec E. „Wpływ procesu azotonasiarczania na zmianę wymiarów czopa wału korbowego odlanego metodą lost foam ze sferoidyzacją INMOLD". Czasopismo Techniczne. 9-M (2012): 33-39.

[6] Brostow W., Czechowski K., Polowski W., Rusek P., Toboła D., Wronska I. "Slide diamond burnishing of tool steels with adhesive coatings and diffusion layers". Materials Research Innovations. 17, 4 (2013): 269-277.

[7] Dobrzański L.A. „Podstawy nauki o materiałach i metaloznawstwo: materiały inżynierskie z podstawami projektowania materiałowego". Warszawa: WNT, 2002. 